\title{
Jerome's letter 108 to Eustochium: Contemporary biography in service of ascetic ideology?
}

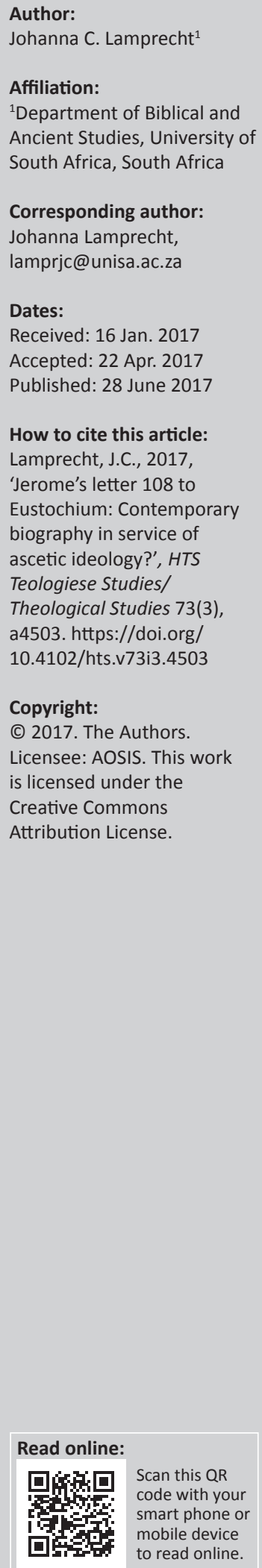

Epistula (Letter) 108, one of the longest of Jerome's letters, was written in 404 AD to console Eustochium for the loss of her mother Paula. Scholars have referred to this letter as a lengthy epitaphium with hagiographic features, a eulogistic tribute, a biographical eulogy of Paula, a laudatio funebris, a travelogue, a memoir, a metaphorical account of Paula's pilgrimage through life, a piece of ascetic propaganda and a textual basis for a Bethlehem-centred cult of Paula the ascetic martyr-saint. The aim of this article is to analyse and comment on Jerome's letter as an example of the genre of Graeco-Roman biography, containing various features of ancient Bíot. While Jerome cast the letter ostensibly as a consolatio for Eustochium, it turned out to be a commemoration of Paula, his patron, devoted disciple and monastic companion. The article will ultimately investigate whether this letter was written to sub-serve a higher motive of Jerome, the chief architect of 4 th-century asceticism.

\section{Introduction}

Epistula 108 by Jerome is a complex and fascinating piece of literature and one of his longest extant works classed as letters. ${ }^{1}$ It is a fine example of multilayered Hieronymian writing. ${ }^{2}$ It was written in $404 \mathrm{CE}$ ostensibly ${ }^{3}$ to console Eustochium for the loss of her mother Paula. Jerome was however not just offering consolation to Eustochium, he was also paying tribute to his very dear friend and companion in a detailed biographical commemoration of her life. And when the historical Paula was 'refracted by the lens of his narrative' (Cain 2010:137), she seems to become the female personification of Jerome's ascetic ideology, and an embodied attestation of his spiritual mentoring.

Most of what is known about Paula is derived from Jerome's letters to and about her, ${ }^{4}$ and in the prologues of many of his works of translation and exegesis. ${ }^{5}$ We have to keep in mind that our sources are literary, written about a woman from the Roman elite class, by a man, constrained within the contemporary social and literary conventions, in a time where misogyny was prevalent in the writings of the church fathers. The letter, with its obvious rhetorical and tributary elements, could raise questions about the correctness of the historical information (indicated and alluded to in several instances of this research report) and the authenticity of the male voice, especially in view of the fact that Paula's wealth contributed significantly to Jerome's literary endeavours (Clark 1986:23-27, 53 n.2).

Jerome met Paula in Rome in the summer of 382 CE when the eastern bishops Paulinus of Antioch and Epiphanius of Salamis visited Rome on ecclesiastical business, with himself accompanying them as their interpreter. She spent much time with them and even hosted Epiphanius at her house. Paula was inspired by their virtues and by Jerome's eremitic persona and knowledge of the 1.The letter takes up 45 pages in the CSEL Vol. 55 edition. All references follow the chapter numbering of this text. Where the chapter
numbering of the NPNF translation differs, different references are given in brackets.

2 Another being Epistula 117.

3.Ep. 108.2: ... cum Eustochium, uirginem et deuotam Christo filiam, in cuius consolationem libellus hic cuditur, procul a nobili genere sola fide et gratia diuitem reliquerit: for she has left her daughter Eustochium - a virgin consecrated to Christ for whose comfort this sketch

is made - far from her noble family and rich only in faith and grace (CSEL Vol. 55:308).
Almost all translations quoted are those by W.H. Fremantle in NPNF Vol. 2-06 (Jerome 1983). In instances where archaic English is used in his translation, the translation is slightly amended to reflect contemporary language, and indicated as such.

4.As seen in a catalogue of his works, De uiris illustribus, ch.135 (Jerome, 1845 in PL, Vol. 23, c.956, p. 720): Epistolarum autem ad Paulam et Eustochium, quia quotidie scribuntur, incertus est numerus. - 'the number of letters (written) to Paula and Eustochium is however uncertain, because they are written every day' (author's own translation).

5.Jerome often emphasises Paula's role in his work: he lists his commentaries on 12 smaller prophets in his third book on Amos, addressed to his friend and Paula's son-in-law Pammachius, and reminds him that he had completed the first four prophets not in the order in which they are found in the Old Testament but in the order in which Paula and Eustochium had requested them. The same kind of reference to Paula can be found in the prologues to the commentaries on Joel, Hosea, Isaiah, and Ezekiel, and in the preface to the translation of Joshua. 
mystical monastic culture of the East. And that was the beginning of Jerome's closest relationship, which lasted until her death in 404 CE - a friendship based on devotion to a shared ideal.

Jerome was absolutely devastated by Paula's death. Their lives had been closely intertwined for almost 20 years - he was her mentor and spiritual guide, she his patron, devoted disciple and monastic companion. He writes in Ep. 108. 32(33) to Eustochium:

I have spent the labour of two nights in dictating for you this treatise; and in doing so I have felt a grief as deep as your own. I say 'in dictating' for I have not been able to write it myself. As often as I have taken up my pen and have tried to fulfil my promise, my fingers have stiffened, my hand has fallen, and my power over it has vanished. The rudeness of the diction, devoid as it is of all elegance or charm, bears witness to the feeling of the writer. (CSEL Vol. 55:308; translation from NPNF Vol. 2-06)

And even in the process of writing this letter, he procrastinated the moment where he actually had to recount her dying moments (Ep. 108.27[28]):

What troubles you, my soul? Why do you shudder to approach her death? I have made my letter longer than it should be already; dreading to come to the end and vainly supposing that by saying nothing of it and by occupying myself with her praises I could postpone the evil day. (translation amended)

For some months after Paula's death Jerome could not undertake any literary work as he fell sick with a raging fever. He confessed to Theophilus ${ }^{6}$ that it was only with difficulty and after long delay that he could summon the strength to resume his work. J.N.D. Kelly (1975:278) is probably right when he say that Jerome suffered the loss 'of one of the very few people in the world, perhaps the only one, for whom he felt real tenderness and affection'. Jerome possibly derived some therapeutic benefit from writing the letter to Eustochium, and may have regarded it as an exercise in self-consolation and closure.

The work can roughly be divided into five sections. The first section (Chapters 1-2) is a kind of preface in which Jerome addresses the 'reader', expressing his authorial intent $^{7}$ and sketching in broad outlines Paula's life, character and influence. He declares that the work is meant to comfort Eustochium and that he intends to give a true testimony about Paula. This preface already contains some of the traditional tópoi of Christian consolation. The second section (Chapters 3-6) is the actual beginning of his narrative, Paula's life-story ${ }^{8}$ : he touches on her noble lineage, her family and her decision to leave Rome for the Holy Land. The third section (Chapters 7-14) is a detailed

6.Ep. 99.1: 'All of a sudden I have lost her who was my consolation' (CSEL 55:211).'

7.Authorial intention is a very important concept in biography: what does the biographer seek to communicate, is it the historical and factual truth about a person's life, or an encomiastic account, or a more broadly ideological message exemplified by a person's life, and to what extent do textual strategies in a biography allow the reader to identify such intentions?

8.Ep. 108.3: Carpamus igitur narrandi ordinem (CSEL 55:308). narration of her journey to and pilgrimage through the Holy Land and Egypt in late 385 and early 386 CE. The fourth section (Chapters 15-26) contains a compendium of anecdotes illustrating her holy and virtuous character, while the fifth section (Chapters 27-34) consists of a riveting account of her death and burial, followed by the two grave inscriptions composed in hexameters by Jerome, and finally her obituary. It is important and interesting to note how Jerome, in the manner of a ring composition established in the preface (Ep. 108.1) and the tomb inscription (Ep. 108.33), introduces an important theme in Paula's life: a noble woman's noble choice for ascetic renunciation (Cain 2010:116-117, 131).

The aim of this paper is to identify and briefly discuss the different layers contained in the letter, and in particular to analyse and comment on it as an example of the genre of Graeco-Roman biography, containing various generic conventions of ancient Bíot. While Jerome apparently cast the letter as a consolatio for Eustochium, it turned out to be a commemoration and biography of Paula, with a hagiographic dimension. The paper will ultimately investigate whether this letter was written to sub-serve a higher motive of Jerome, the chief architect of 4th-century asceticism.

It is important to note that Epistula 108 was not, and should not, be studied in isolation. Reference will be made to other letters written by Jerome where relevant.

\section{Epistula 108 as Consolatio}

Although Jerome briefly states that he writes the letter to comfort Eustochium (Ep. 108.2) and that his grief is as deep as her own (Ep. 108.32), the consolatory element is very slight (Scourfield 1993:27). Paula's consecrated virgin daughter is only once directly addressed (in Ep. 108.31), ${ }^{9}$ while several aspects of the letter indicate that it was addressed to a larger audience and intended to circulate broadly. ${ }^{10}$ At three places, Jerome addresses the 'reader' (lector: Ep. 108. 2, 21, 33). He describes Paula and her pilgrimage as if the intended reader does not know her well, he speaks about Eustochium in the third person (e.g. in Ep. 108.27 where he describes how she nursed her dying mother), and he motivates the inclusion of the two grave inscriptions at the end with these words:

And I have cut an inscription on your tomb, which I append; that, wherever my narrative may go, the reader may learn that you are buried at Bethlehem and commemorated there. (Ep. 108.33 [34; [author's own emphasis]; translation amended)

Almost at the end of the letter (Ep. 108.32) Jerome casually mentions that he was fulfilling a promise when he wrote the letter - was it a promise to Eustochium, or to a closed

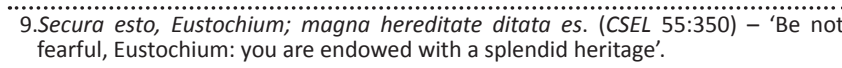

10.As was also the case with Letter 22, written in 384 CE to Eustochium; Kelly (1975:117); Cain (2010:117). 
community in Bethlehem, or perhaps to his esteemed friend Marcella in Rome?

From time to time the story of Paula's life is interspersed with some of the traditional tópoi of Christian consolation: 'we do not grieve that we have lost her, rather we thank God that we have had her' (Ep.108.1); 'if Paula's friends grieve, it is not for her, for she is at last with Christ and the heavenly mansions have gained her' (Ep.108.1); 'now she enjoys the crown of righteousness' (Ep.108.22); 'once she wore haircloth, but now a white garment' (Ep.108.22; translation amended); 'she has won the crown of martyrdom, for a life like hers is made up of daily martyrdoms' (Ep.108.31 [32]); 'her faith and works unite her with Christ' (Ep.108.33 [34]), and 'standing in his presence she can the more readily gain what she asks' (Ep.108.33 [34]).

Paula's reputation as virtuous, suffering servant of Christ was widespread, and in Ep. 108.28-29 Jerome uses exaggeration when he refers to all who attended her funeral, thereby increasing the stature of the deceased to comfort Eustochium by suggesting or reminding her that her grief is shared by many others.

The author's main concern, however, is not consolation, albeit cast in the artificial forms prescribed by the genre (Favez 1937) but clearly to celebrate the praises of Paula - the result being rather a memoir, or an obituary, with considerable biographical content (Scourfield 1993:27).

\section{Epistula 108 as encomium ${ }^{11}$ and rhetorical masterpiece}

A conventional component of the ancient consolatio was the eulogy or encomiastic section in which the author praised the virtues of the deceased. Jerome, being keenly aware of how easily eulogy can lend itself to hyperbole, repeatedly calls Jesus and his angels as witnesses that he has produced a true and realistic portrait of the virtuous Paula. ${ }^{12}$ In this case, however, the encomiastic section encompasses the entire consolatio in a true hyperbolical fashion.

Scholars have referred to this letter as a lengthy epitaphium (Cain 2010:105, 107, 124; Diederich 1954:369; Kelly 1975:279; Scourfield 1993:83) with hagiographic features, a eulogistic tribute (Diederich 1954:369), a biographical eulogy of Paula (Hickey 1987:21; Kelly 1975:279), a laudatio funebris (Diederich 1954:369; Scourfield 1993:31), a threnody in the form of a consolatory letter (Kelly 1975:278), an encomium for Paula (Clark 1986:213; Kraemer 2008:469), a panegyric (Coleiro 1957:162; Kelly 1975:279), a travelogue (Kelly 1975:117), a memoir (Scourfield 1993:27), an obituary with considerable

\section{Encomium is an important type of rhetoric in praise of a person.}

12.See Ep. 108.2: 'Testor lesum et sanctos angeloseius ipsumque proprie angelum, qui custos fuit et comes admirabilis feminae, me nihil in gratia, nihil more laudantium sed, quidquid dicturus sum, pro testimonio dicere ...' (CSEL 55:307): I call Jesus and his saints, yes and the particular angel who was the guardian and the companion of this admirable woman to witness that these are no words of adulation and of this admirable woman to witness that these are no words of adulation and
flattery but sworn testimony every one of them borne to her character. Translation flattery but sworn testimony every one of the biographical content (Kelly 1975:117; Scourfield 1993:27-28), a metaphorical account of Paula's pilgrimage through life (Weingarten 2005:219-265), a piece of ascetic propaganda (Cain 2010:137), a textual basis for a Bethlehem-centred cult of Paula the ascetic martyr-saint (Cain 2010:105, 108, 124), and a Life of Paula (Weingarten 2005:219-265).

Jerome himself states (Ep. 108.21) that he is writing 'history, or a memoir', and not a panegyric: ${ }^{13}$ Testor Iesum, cui illa seruiuit et ego seruire cupio, me in utraque parte nihil fingere, sed quasi Christianum de Christiana, quae sunt uera, proferre, id est, historiam scribere, non panegyricum, et illius uitia aliorum esse uirtutes. (CSEL 55:338) ${ }^{14}$ Elsewhere he refers to this work as a libellus (Ep. 108.2), a narrative (Ep. 108.3), a liber ${ }^{15}$ (Ep. 108.27, 32) and noster sermo (Ep. 108.33).

When Jerome mentions that he worked only two nights on the letter, he also apologises for the resulting 'rudeness of diction, devoid as it is of all elegance or charm, bearing witness to the feeling of the writer' (Ep. 108.32 (33)). Kelly (1975:279) however has a different opinion:

In fact it is a work of consummate art, as much in its prose as in its general design. Sentence after sentence dazzles the reader with its careful construction, its euphonious cadences. All the devices of rhetoric are deployed with studied effect, and one admires the skilful use of abundant and aptly chosen quotations from Scripture, occasionally one from Vergil and other classical authors too ... Nevertheless the artificial forms prescribed by the genre cannot conceal the intense regard and genuine emotion pervading the panegyric. (See also Diederich 1954:369-372)

But this affectation of modesty could also have another purpose - to function as a form of self-promotion in service of his ascetic ideal (which will be discussed below).

At the very beginning of the letter (Ep. 108.1)and with typical rhetorical flourish, Jerome expresses doubt in his own ability to do justice to the virtues of the holy and venerable Paula: $S i$ cuncta mei corporis membra uerterentur in linguas et omnes artus humana uoce resonarent, nihil dignum sanctae ac uenerabilis Paulae uirtutibus dicerem (CSEL 55:306):

If all the members of my body were to be converted into tongues, and if each of my limbs were to be gifted with a human voice, I could still do no justice to the virtues of the holy and venerable Paula. (CSEL 55:306; translation from NPNF Vol. 2-06)

Self-depreciation of this kind usually has a eulogistic function, where the object of praise is made even more 13.See Hägg and Rousseau (2000), for elaborate discussions on the similarities and differences between these two genres.

14.I I call that Jesus whom she served and whom I desire to serve to be my witness that so far from unduly eulogizing her or depreciating her I tell the truth about her as one Christian writing of another; that I am writing a memoir and not a panegyric, and that what were faults in her might well be virtues in others less saintly'.

15.It seems that this was the terminology preferred by Jerome for his letters or treatises. In his epistolatory exhortation to virginity (Ep. 130), addressed to Demetria in 414 CE he refers to his most celebrated treatise on virginity, Ep. 22 to Demetria in 414 CE he refers to his most celebrated treatise on virginity, Ep. 22 to Eustochium, written in $384 \mathrm{CE}$ by using the term liber. Jerome was criticized for his satirizing of the 'worldly' lifestyles of some Christian clerics, but maintains that the criticism was unfounded and that those critics come and go, but his 'book' will stay: liber manet, homines praeterierunt. This formulation is attested in only one other place in all of extant Latin literature, in Pliny the Younger's (1982) Ep. 9.27.2 to Paternus. Cf. Cain (2008:708-710). 
distinguished by the author's avowed inability to tell fittingly of the praiseworthy qualities of his subject. In defending his extravagant praise of Paula, he later says (Ep. 108.15) that his critics must not insinuate that he is drawing on his imagination or decking her, like Aesop's crow, with the fine feathers of other birds.

Jerome's encomium begins in conventional rhetorical manner with a laudatio of Paula's ancestry. In referring to the forefathers of the deceased Jerome was following a standard formula for funerary discourses (See Hägg and Rousseau 2000:140-179). ${ }^{16}$ He clearly states, however, that 'others' and 'men of the world' (meaning, other authors/biographers/ panegyrists) may focus on a person's illustrious ancestors, but that he will only praise Paula, whom he compares to a shining and precious jewel. In the case of Epistula 108 the inclusion of a noble family-tree was presumably done only to emphasise the nobility of Paula's ascetic rejection of her distinguished descent (Hickey 1987:21-22, 119 n.1). Jerome regards her as 'noble' by reason of her Christian virtues, and not by reason of her noble ancestry.

True to character, Jerome from time to time adds a mordant quality to the work by using satire and invective: when he extols Paula's virtues, he immediately lashes out against the vanities and self-indulgence of lesser women (Ep. 108.3, 6).

Examples of rhetorical figures of speech are abundant. I quote just a few: antithesis ('rich formerly in this world's goods, she is now more distinguished by the poverty that she has embraced for Christ' $-E p$. 108.1; '... who while she lived at Rome was known by no one outside ... by hiding herself at Bethlehem become the admiration of all lands Roman and barbarian' - Ep. 108.3; 'The strongest winds seemed weak and the greatest speed slow' - Ep. 108.7); comparison ('As among many jewels the most precious shines more brightly, and as the sun with its beams obscures and puts out the paler fires of the stars; so by her lowliness she surpassed all others in virtue and influence and, while she was least among all, was greater than all' - Ep. 108.3; and 'Indeed so ardent was her faith that she even licked with her mouth the very spot on which the Lord's body had lain, like one thirsty for the river which he has longed for' Ep. 108.9; translation amended); evidentia ('And here she was filled with terror by the marvels she beheld; for she saw demons screaming under different tortures before the tombs of the saints, and men howling like wolves, baying like dogs, roaring like lions, hissing like serpents and bellowing like bulls. They twisted their heads and bent them backwards until they touched the ground; - Ep. 108.13); and metaphor:

Until now the wind has been all in my favour and my keel has smoothly ploughed through the heaving waves. But now my speech is running upon the rocks, the billows are mountains high, and imminent shipwreck awaits both you and me. (Ep. 108.27 [28], translation amended)

16.The most accomplished piece of panegyrical oratory in late antiquity is Gregory of Nazianzus's (1992) funeral speech for Basil of Caesarea written in c. 381 CE (Oratio 43).
After the account of Paula's noble ancestry and family, the encomium stresses in eloquent and moving lines Paula's social service among the poor in Rome after her husband's death. In a series of rhetorical questions Jerome refers to her kindness, compassion, lavish charity and care for the poor, the hungry and sick throughout the city, even to the point of robbing her children of their inheritance (Ep. 108.5).

The account of Paula's heart-rending leave-taking of her children and family (Ep. 108.6) is laden with pathos and dramatic effect, and with Vergilian ${ }^{17}$ and Horatian reminiscences interspersed in thought and diction. It is one of the best examples of Jerome the classically trained artist at work. His portrayal of Paula's departure, with her daughter Rufina and her little son Toxotius sobbing on the quay and entreating their mother not to abandon them, while 'Paula's eyes were dry as she turned them heavenwards; and she overcame her love for her children by her love for God', is all the more poignant, because Jerome was not an eye-witness to the episode - he had left Rome several weeks earlier. The rhetoric and dramatic detail was overdone with another purpose: to stress her noble subordination of maternal feeling to her higher devotion to God (Hickey 1987:24-25). ${ }^{18}$

Jerome aptly concludes his encomium for Paula with his own formal verse-compositions, inscribed in her burial place: the first inscription is the epitaph on Paula's tomb (Titulus sepulchri), extolling her noble lineage and her claim to be the first Roman aristocrat to embrace Christ's poverty and come to Bethlehem:
Titulus sepulchri:

Scipio quam genuit, Pauli fudere parentes,

Graccorum suboles, Agamemnonis inclita proles hoc iacet in tumulo, Paulam dixere priores.

Eustochiae genetrix, Romani

pauperiem Christi, et Bethlemitica rura secuta est. (CSEL 55:350) prima senatus:
Within this tomb a child of Scipio lies, A daughter of the renowned Pauline house,

A scion of the Gracchi, of the stock

Of Agamemnon's self, illustrious:

Here rests the lady Paula, well-beloved

Of both her parents, with Eustochium

For daughter; she the first of Roman ladies

Who hardship chose and Bethlehem for Christ.

(Ep. 108.33 (34), translation amended)
17.See Diederich (1954:370): 'supplex manus ad litora tendit' [Virgil 1978 (Aen 3.592)]; 'oculos aversa tenebant' (Virgil 1978 [Aen. 1.482]), with inflectional variations.

18. Hickey also refers to the similarity of this passage to a poetic form common to classical authors, called the proemptikon: 'Jerome is using elements of the classical authors, called the proemptikon: 'Jerome is using elements of the
proemptikon to embellish his monastic view of the subordination of maternal sentiment'. 
The other verse-inscription links her last resting place with Christ's crib, carved on the entrance of the nativity grotto (in foribus speluncae):

$\begin{array}{ll}\begin{array}{l}\text { Despicis angustum, praecisa } \\ \text { rupe sepulchrum? }\end{array} & \begin{array}{l}\text { 'Here you see hollowed in } \\ \text { the rock a grave, }\end{array} \\ \begin{array}{l}\text { Hospitium Paulae est, } \\ \text { coelestia regna tenentis. }\end{array} & \begin{array}{l}\text { This is Paula's tomb; high } \\ \text { heaven has her soul. }\end{array} \\ \begin{array}{l}\text { fratrem, cognatos, Romam } \\ \text { patriamque relinquens, }\end{array} & \text { Who Rome and friends, } \\ \text { divitias, subolem, } & \text { riches and home forsook } \\ \text { Bethlemitico conditur antro. } & \text { Here in this lonely spot to } \\ \text { hic praesepe tuum, Christe, } & \text { For here Christ's manger } \\ \text { atque hic mystica reges } & \text { was, and here the kings to } \\ \text { munera portantes hominique } & \text { Him, both God and man, } \\ \text { deoque dedere. } & \text { made their offerings'. } \\ \text { (CSEL 55:350-351) } & \text { (Ep. 108.33 (34); translation } \\ & \text { amended) }\end{array}$

The letter concludes with a formal obituary:

\begin{tabular}{|c|c|}
\hline $\begin{array}{l}\text { Dormiuit sancta et beata } \\
\text { Paula, septimo Kalendas } \\
\text { Februarias, tertia sabbati post } \\
\text { solis occubitum. sepulta est } \\
\text { quinto Kalendarum } \\
\text { earumdem Honorio Augusto } \\
\text { VI et Aristaeneto consulibus. } \\
\text { uixit in sancto proposito } \\
\text { Romae annos quinque, } \\
\text { Bethleem annis uiginti. omne } \\
\text { uitae tempus impleuit annis } \\
\text { quinquaginta sex, mensibus } \\
\text { octo, diebus uiginti uno. }\end{array}$ & $\begin{array}{l}\text { 'The holy and blessed Paula } \\
\text { fell asleep on the seventh } \\
\text { day before the Kalends of } \\
\text { February, }{ }^{19} \text { on the third day } \\
\text { of the week, after the sun } \\
\text { had set. She was buried on } \\
\text { the fifth day before the same } \\
\text { Kalends, in the sixth } \\
\text { consulship of the Emperor } \\
\text { Honorius and the first of } \\
\text { Aristaenetus. She lived in } \\
\text { the vows of religion five } \\
\text { years at Rome and twenty } \\
\text { years at Bethlehem. The } \\
\text { whole duration of her life } \\
\text { was fifty-six years eight } \\
\text { months and twenty-one } \\
\text { days'. } \\
\text { (Ep. } 108.33 \text { [34]) }\end{array}$ \\
\hline
\end{tabular}

Jerome thus painted a glittering portrait of Paula in this encomium/threnody, a portrait which is, fortunately for posterity, in the main biographical (Kelly 1975:278).

\section{Epistula 108 as Biography}

The genre of biography or 'life writing' also encompasses other narrative forms such as letters, memoirs, journals, diaries, hagiography and autobiography, and it shares many features with these literary genres. Biography sometimes even masqueraded as a letter. Is this the case with Epistula 108?

In a fairly recent (1992; 2013) genre-critical study of the Gospels, Richard Burridge (2013:9-30) $)^{20}$ identified

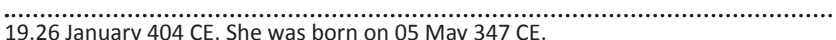

20. His work resulted in lively scholarly debate and numerous reviews and studies (e.g. by Hägg, Frickenschmidt), as discussed on pp. 19-21. Within a decade of the publication
of his revised thesis, New Testament scholarship came to accept the biographical genre of his revised thesis, New Testament scholarship came to accept the biographical genr of the gospels and focussed their research on the implications thereof. biography ${ }^{21}$ as the literary genre of the Gospels, based on his study and systematic analysis of both internal and external generic features of ancient Graeco-Roman bioi and vitae and related genera proxima (such as encomium).22 The genre of Graeco-Roman biography has several distinctive characteristics, albeit with some flexibility. These include an authorial preface or introduction, presenting the birth of the subject and/or a general overview of the work, the person's ancestry, anecdotes ${ }^{23}$ of the person's youth or life, a chronological narrative of events of the subject's life and career, mostly written in continuous prose narrative, the possible inclusion of poetry, speeches, sayings and sermons, the author's active display of character through the subject's words and deeds, and finally an account of the final days and death of the subject.

The merit of Burridge's work is that he has reduced the matter of genre to a set of criteria - flexible but identifiable - that can be applied to any work proposed (Hillman 2012:2). These criteria include external features (to do with form and structure, such as mode of representation, size and length, structure, scale, literary units, use of sources, and methods of characterisation), as well as internal features (to do with content, such as birth and ancestry, the person's public life, the dramatic settings, authorial intention which may include apologetic or polemic or didactic, quality of characterisation, and a major concentration on the person's death). Christian biography developed in the 3rd and 4th centuries CE, based on the earlier pagan models but was often more hagiographical, legendary, and focused on acts like martyrdom.

When Epistula 108 is analysed according to the criteria identified by Burridge, it closely fits the ancient pattern of Lives and shares most of the generic features of GraecoRoman biography.

Jerome begins his biographical letter with a preface stating authorial intent and a brief summary of Paula's ancestry, life and virtues, interspersed with quotations from Scripture (Ep. 108.1-2).

He then praises her ancestry ${ }^{24}$ and family, implying that her greatness sprang from the greatness of the noble line, and thereby conforming to the established tradition of Roman biography (Ep. 108.3-4). Jerome was, however, also working within the newer tradition of Christian biography which praised an illustrious ancestry only to emphasise

21.Biography is in recent times handled as an inclusive literary genre in the domain of New Testament studies and Graeco-Roman literary criticism, due to the scholarly work of inter alia Aune (1988), Momigliano (1993), Barton (2006) and Burridge (2013).

22.For his comparative study Burridge selected a group of Lives, written in Greek and Latin, from the earliest examples of ancient biographical writing dating from a few centuries before the Gospels to later works, dating a couple of 100 years after the gospels, as listed in Burridge (2013:16).

23.Anecdotes are a type of memory or reminiscence of an interesting event, captured within a narrative.

24.According to Hickey (1987:22-23) research done by Jones et al. and reported in The Prosopography of the Late Roman Empire calls into question the impeccable pedigree claimed by Jerome. The evidence suggests that whatever status Paula hedigree claimed by Jerome. The evidence suggests that whatever status Paula had in her ancestry came primarily through
ascertain how wealthy Paula exactly was. 
the saint's humility, and her shunning of earthly glory in favour of virtue. With this he introduces an important theme: a noble woman's noble choice for (ascetic) renunciation of comfort and all that formed part of luxurious urban life. By the 4th century Christians had developed the concept of an eschatological or spiritual family instead, headed by God the Father, joined allegorically by the Mother Church and devoted to the precepts of the Son. To this Jerome added the idea of the dedicated virgin bride of Christ ${ }^{25}$ and a reversal of normal family relationships and sentiments. Paula and Eustochium, and their female contemporaries rejected marriage and motherhood, and fled the confines of the traditional family system, pursuing a life that offered them more autonomy and self-expression. ${ }^{26}$ Jerome therefore focuses on their ascetic choices in his enumeration of Paula's five children. Paula, the (celibate) mother, Blesilla the (celibate) widow, and Eustochium the inviolate virgin, are pictured as female exemplars of Jerome's ascetic ideal.

Space do not allow an elaborate discussion on each of the features of biography contained in Epistula 108 - I will therefore only refer to a few that meet the requirements of a Life/Vita.

- An analysis of verb subjects in Epistula 108 shows that Paula is the grammatical subject of almost $50 \%$ of the verbs. Although Paula was accompanied by Jerome, Eustochium and many other virgins on her pilgrimage to the Holy Land and Egypt, the action occurring in the narrative revolves around her and what she saw and experienced.

- Jerome incorporated literary units such as anecdotes (especially in and after the travelogue, with a view to illustrating Paula's sanctity in action), poems (Ep. 108.7, 33), teachings (Ep. 108.23-26), prayers (Ep. 108.19) and sayings (Ep. 108.7-14) in the continuous narrative form. The most striking anecdote is without doubt Paula's visit to the (alleged) tomb of Jesus Christ in Jerusalem: when she entered the tomb she was so overtaken by emotion that she repeatedly licked the spot where his body had lain, as if she were dying of thirst (Ep. 108.9). He also relates an incident when Paula was attacked by a violent fever and admonished by the doctors to take a little light wine. Paula refused, and Jerome appealed to pope Epiphanius to try to convince her, but she perceived the stratagem. When Jerome asked the pope whether he could accomplish anything, his answer was: '... old as I am I have been almost persuaded to drink no more wine' (Ep. 108.21).

- Paula's character is displayed through her words and deeds (Ep. 108.16-17, 26), as well as through Jerome's observations (Ep. 108.6, 15).

25.Epistula 22, Jerome's famous treatise on Virginity in the form of a letter layin down the motives that should compel those who devote themselves to a life of virginity, and rules for their daily conduct. As Eustochium became the virgin bride virginity, and rules for their daily conduct. As Eustochium became the virgin bride of Christ, Jerome congratulated Paula on becoming the mother-in-law of God (Ep. 22.20). This letter addressed to Eustochium in $384 \mathrm{CE}$ is generally considered to be
the finest expression of his ascetic doctrine.

26.Cf. the studies by inter alia Clark (1986), Cox Miller (1993), Clark (1999), Curran (2000), Hickey (1987), McNamara (1984), Simpson (1988), et cetera.
- The source of a large part of the Vita is Jerome's own experience and observations, resulting in an eyewitness account of most of Paula's life events, which help lend authenticity and immediacy to the biography.

- There is a marked precision in the provision of details of place and time, especially in the travelogue or iter (Ep. 108.7-14) and in the description of the order of Paula's monastery (Ep. 108.20-21). Cain (2010) comments as follows on the narrative of the iter:

In the account of Paula's travels the reader is met with picturesque ekphraseis of sacred sites complemented by emotionally charged descriptions of what it is like for a devout Christian to experience these sites first-hand. For each sacred place she visited Jerome provides a brief excursus highlighting relevant points of biblical-historical interest of the sort that pilgrims might find edifying. (p. 120)

- The narrative is mainly chronological, with descriptive passages interspersed in the chronology - virtues, physical appearance (Ep. 108.15, 21).

- Jerome assigns dialogue to Paula in the narrative. In almost every case the dialogue consists of recitation of biblical passages from memory. Jerome asserts that she had known the Holy Scripture by heart (scripturas tenebat memoriter - Ep. 108.26 (CSEL 55:344)). Paula was so saturated in the Scriptures that she knew a verse to meet every adversity (Ep. 108.18, 19). She used passages from Scripture as God's armour against the assaults of wickedness, sickness and infirmity (brought on by incredible abstinence and by redoubled fasts), and the onslaughts of envy and jealousy which were manifested against her. But Jerome also adds, albeit with a touch of modesty, that Paula studied the Scriptures 'under his guidance' (me disserente - Ep. 108.26) and that he taught her what he had learned from the church's most famous writers. The tone of the work is serious and the style descriptive.

- The scale of the work is narrow in the sense that it deals only with Paula's life, more specifically the last 20 years of her life.

- There are clear antagonists such as 'Hadad the Edomite', tribulations and afflictions referred to in Ep. 108.18, sicknesses and infirmities, also of her son Toxotius in Rome (Ep. 108.19), and the anonymous heretic (Ep. 108.23-25; translation slightly amended):

From that day forward so profoundly did Paula commence to loathe the man - and all who agreed with him in his doctrines - that she publicly proclaimed them as enemies of the Lord. I have related this incident less with the design of confuting in a few words a heresy which would require volumes to confute it than with the object of showing the great faith of this saintly woman who preferred to subject herself to perpetual hostility from men rather than by friendships hurtful to herself to provoke or to offend God.

- Throughout the vita there are motifs such as renunciation, humility, nobility, pilgrimage, virtue, poverty and wealth, the Holy Scriptures and martyrdom.

- There is a major concentration on Paula's death with a detailed treatment of her last days (Ep. 108.22, 27-34). 
Paula's lifestyle of renunciation and abstinence has clearly transformed all aspects of her life and made her a subject for biography. Her actions and choices were dominated by one concern: to preserve a singular attachment to God by practising detachment from the world through physical deprivation, poverty, humility and the preservation of chastity. Her seemingly total renunciation of family and the world enabled her to concentrate all her attention on God, through prayers, fasting, the study of Scripture and pilgrimage.

Jerome presented Paula as the ascetic heroine ${ }^{27}$ and exemplar of true Christian commitment in a time when commitment was no longer tested by martyrdom and the ascetic life became a suitable bloodless substitute (Clark 1995:33). Jerome speaks of Paula in these terms:

... your mother has now after a long martyrdom won her crown. It is not only the shedding of blood that is accounted a confession: the spotless service of a devout mind is itself a daily martyrdom. Both alike are crowned; with roses and violets in the one case, with lilies in the other. (Ep. 108.31)

\section{Epistula 108 as multilayered work of literature}

A careful reading of Epistula 108, with Jerome's intent as point of departure, has thus revealed the letter as a multilayered piece of literature.

Jerome states his intent clearly in two places, as indicated previously. In Ep. 108.2 he briefly declares that he writes the letter to comfort Eustochium, and in Ep. 108.21 that he is writing 'history, or a memoir', and not a panegyric. He also emphasises that his aim is to give a true, sworn testimony of Paula's life and virtues, and not adulation or flattery (Ep. 108.15).

This researcher opines that Jerome, as author, seems to hide behind his text for the largest part of the letter (just as a mentor hinds behind his or her disciple). The reader knows from information derived from other letters that Jerome became intimately involved with Paula and her family in Rome and accompanied her on her pilgrimage to the Holy Land and Egypt. Yet his narrative of these two phases is done from the perspective of an omniscient narrator, or at least an objective observer. All the action occurring in the travelnarrative revolves around Paula and what she saw and experienced. Nowhere does he refer to his own experience or impressions of the sacred places. Although the scene of Paula's departure from Pontus is narrated as if it is an eyewitness account, we know that Jerome was not present and must have relied on the reports of other people present, or even of Paula herself. Yet all the time the reader is aware of the mentor behind the scenes.

The first indication of Jerome being an active part of her life occurs in Ep. 108.15, where he states that he reproved her for

27. Paula is venerated in the Eastern Orthodox Church and the Roman Catholic Church as Saint Paula of Rome, Patroness of the Order of Saint Jerome and Patron saint of as Saint Paula of Rome, Patroness of the Order of Saint Jerome
widows. She is commemorated on January 26 (Farmer 2011). giving away all her money and even borrowing some at interest when her liberality knew no bounds. The next instance is in Ep. 108.21, where Jerome describes Paula's serious illness from the perspective of an eyewitness who was indeed involved in the action:

I admit that in this she was too determined, refusing to spare herself or to listen to advice. I will relate what I know to be a fact ... I on my side secretly appealed to the blessed pope Epiphanius to admonish her ... (Translation in NPNF Vol. 2-06)

In both cases, he seems to emphasise that Paula's extreme renunciation was her own choice.

Jerome was also actively involved in the action when Paula was confronted by the anonymous Origenist heretic (Ep. 108.23): 'As the fellow had tried to deceive Paula, I at her request went to him, and by asking him a few questions involved him in a dilemma'. Jerome devoted three long chapters to this digression to recount the incident. Although he pretends that it was not about his learned skills to refute a heresy, it is in fact exactly what he wants to display.

His active involvement in the life-story is most visible during her last days and dying moments, and he recounts this episode with intense and sincere emotion. These eyewitness accounts help lend authenticity and immediacy to the narrative.

I have also established the audience of the letter - ostensibly Eustochium, but in truth the reader, the wider audience.

It is my contention that the letter is multilayered: On the first level it is a consolatio for Eustochium, in fulfilment of a promise or undertaking made by Jerome, cast in the artificial forms prescribed by the genre. A conventional component of the ancient consolatio is the eulogy or encomiastic section in which the author praises the virtues of the deceased. In the case of Epistula 108 the encomium almost eclipses the consolatio, and at the same time the encomium has considerable biographical content and features, as illustrated above. The next step is to establish whether the biography presents itself as conveying history - which is Jerome's stated intention - or does it position itself as pursuing other aims?

In some instances of biography the biographical subject merges with the biographer's own persona and agenda into one ideal whole, just as Antony becomes the spokesperson for Athanasius' view of asceticism. ${ }^{28}$ This process is called 'transference', where biography becomes a vehicle for ideas and the embodiment of ideals. There seems to be such a subtext written into Epistula 108.

Just as it is difficult to find an unbiased historical narrative, in the same way biography can also be written for political, moral or didactic purposes. Biography then often has a hidden agenda, and creates its subject against a backdrop of

28 Burrus (2001:447) arcues that the Athanasian text (The Life of Antony) is the 'source' of Western asceticism and hagiographical literature, and that Jerome 'source' of Western asceticism and hagiographical literature, and that Jerome incited - may make himself the "first" author of holy Lives'. 
family and community. The biographer then presents the subject by highlighting character, achievements and lasting significance in a deliberate act of setting up a person as exemplum. The use of exemplars is a familiar hagiographic technique.

\section{Epistula 108 as propaganda for Jerome's ascetic ideal?}

Jerome was the author of three hagiographic vitae, written between 374 and 391 CE. ${ }^{29}$ Epistula 108, which was regarded by some scholars as a Life of Paula, in a restricted sense also gained a hagiographic dimension (Cain 2010:118, 123-124). Although he does not allude to anything supernatural with regards to Paula's life, and does not credit her with any miracles, he does in fact depict her as a marvel, a miracle:

For what race of men is there which does not send pilgrims to the holy places? And who could there find a greater marvel than Paula? As among many jewels the most precious shines more brightly, and as the sun with its beams obscures and puts out the paler fires of the stars; so by her lowliness she surpassed all others in virtue and influence and, while she was least among all, was greater than all. The more she cast herself down, the more she was lifted up by Christ. She was hidden and yet she was not hidden. By shunning glory she earned glory. (Ep. 108.3, [author's own emphasis]; translation from NPNF Vol. 2-06)

Paula is thus proposed as an exemplum of virtue and ascetic renunciation, ${ }^{30}$ a distinctly Hieronymian model of ascetic piety, pilgrimage, scriptural study, and euergetism (Cain 2010:138). Her life is worthy not just of admiration but also of imitation - just as she was imitated by her daughter Eustochium, her grand-daughter Paula the Younger and the large number of women who joined her pilgrimage and monastery.

Jerome left Rome in August 385 CE under a cloud of suspicion and criticism for a number of reasons, not only concerning the controversial status of many of his distinctive positions and scholarly projects. His career in the church was fraught with discord, repeated exiles and excommunications. His campaign for an intensified asceticism was a major cause of the reaction against him. The Roman clergy and elite criticised his extremist positions on virginity (as seen in Ep. 22 addressed to Eustochium), and his apparent debasement of

29.The Three Lives form a group with particular features of its own, and were written with more or less the same purposes in mind - to write history, to prove his literary abilities and to propase with Athanasius's Life of St Anthony. Tita Hilarionis, written in 391 CE (in other words during Jerome's stay in Bethlehem), is the only Life consisting of a comprehensive narrative of a whole life, although 'the biography is meant to serve a higher theme - to impersonate asceticism'. The basic historical facts in Three Lives are embellished by fictitious dialogues, fanciful details, elaborate descriptions, miracles and imaginary situations, meant to make the narrative more entertaining and vivid but ending up detracting from the historical value of the works. The heroes in Jerome's narratives are not simply morally great, but they are depicted as almost superhuman and faultless, with qualities like fortitude and willpower. The supernatural plays a great part in Three Lives - in the Life of Hilarion 12 miracles are related in detail and many others hinted at. The supernatural also takes the shape of prophesy and the knowledge of hidden things. It is obvious that Jerome builds the personality of his heroes on his own idea of hermit, and on his own experiences of monastic life.

30.Asceticism is understood to be a lifestyle characterised by abstinence from worldly pleasures, often for the purpose of pursuing spiritual goals. That is exactly what Paula chose to do. Asceticism was also regarded as an alternative to martyrdom. Later in $404 \mathrm{CE}$, in the preface to his Vulgate translation of Joshua, Jerome declared that Paula's life is an example of virtue (cuius uita uirtutis exemplum est.) marriage. They believed that this mentality undercut traditional Roman family values and contributed to the extinction of centuries-old bloodlines. ${ }^{31}$ At the same time his encouragement of ascetic-minded members of the elite to spend their inherited fortunes on almsgiving undermined the economic viability of noble families. Jerome was blamed for encouraging Paula's recently widowed daughter Blesilla in an excessive asceticism and rigorous fasting that caused her premature death within 4 months of her conversion. A letter which he intended as a eulogy of Blesilla (Ep. 39) soon turned into a rebuke of Paula for displaying excessive grief over the loss of her daughter, because it reflects badly on his teaching and mentorship and damages the reputation of his ascetic ideology (Littlechilds 2014:97-111). Jerome was further criticised for the attitudes exposed in this letter. His position deteriorated even further with the death of Pope Damasus at the end of $384 \mathrm{CE}$, who had been his patron and ardent admirer of his exegetical and scholarly abilities (Cain 2006a:729-730; Curran 2000:272-323; Hickey 1987:21-26; Kelly 1975:82-90). During his 3 years in Rome Jerome lived in mental and emotional intimacy with his circle of ascetic noble women, which included Paula and Eustochium. He described the nature of their relationships in his Epistula 45 addressed to Asella just before he left Rome for Palestine in 385 CE: ‘Our studies made for constant association, which ripened into familiarity, which in turn produced mutual confidence'. He reminded Asella that he enjoyed acclaim as a mentor to studious women (Ep. 45.2). The same letter also contains Jerome's rebuttals of some suspicious rumours spread concerning his relationship with Paula. The church authorities apparently launched an investigation into allegations of sexual impropriety and clerical misconduct (Cain 2006a:730; Littlechilds 2014:108, n. 53; Kelly 1975:104-115).

It is clear from all these allegations that Jerome was seriously criticised for his ascetic ideologies before he left Rome, and he applied himself to reinforcing his own spiritual authority. He had to craft a literary self-presentation in his quest for patronage, scholarly independence and a position of authority. His letters, including Epistula 108, perhaps can be described as interlocking propagandistic works of literature, which functioned effectively as a form of self-promotion. Jerome presented himself as the foremost authority of ascetic Christianity and biblical scholarship. ${ }^{32}$

At the same time he presented Paula in Epistula 108 as the epitome of his ascetic ideal. The imprint of his mentorship is most apparent in his praise of her zeal in scriptural study. She also became so fluent in Hebrew that she could chant the Psalms without a trace of a Latin accent (Ep. 108.26), and her last words were spoken in Greek (Ep. 108.28). As femina trilinguis she was the female counterpart to Jerome's vir trilinguis (Cain 2010:123).

In Ep. 108.31 Jerome compared Paula to Abraham, because she was willing to leave her country and kin to obey the call

31.Cf. the defamilialisation of Roman society in Yarbough (1976:154-157); Clark (1999:196-203).

32.'In his correspondence Jerome idealized some of his female monastic associates from Rome in order to legitimize his controversial ascetic and scholarly programs (Cain 2009:121, n. 9). 
to perfection (Matt 19:21). He urged Paula after the death of Blesilla to do what Abraham did (Ep. 39), to renounce her child, like Abraham did with the near-sacrifice of Isaac - and that was exactly what Paula did (Clark 1999:196).

Jerome highlighted Paula's virtuous character and noble lifestyle in Ep. 108, and the letter contains ample evidence of his intense regard for her and the genuine emotions he experienced at her death. Yet there seems to be a sub-text written into the Letter. It is addressed to a larger audience, and the many subtle references to the ascetic life and Paula's noble choices cannot be ignored. Read in the context of all his correspondence, the reader is left with the impression that Jerome attempted to reinforce his own spiritual authority and to propagate his ascetic ideologies.

\section{Conclusion}

In the only passage directly addressing his departed patron and protégée, and fully conscious of his achievements, ${ }^{33}$ Jerome has a final request. Just as Paula, in life, had been the support and validation of his labours, she must now, from beyond the grave, as intercessor, continue to assist her mentor:

Uale, Paula, et cultoris tui ultimam senectutem orationibus iuua. fides et opera tua Christo te sociant, praesens facilius, quod postulas, inpetrabis - 'Farewell, o Paula, and aid with your prayers the old age of your cultivator (= mentor). Your faith and your works unite you to Christ, (and) thus being in his presence you will more readily obtain what you request' (Ep. 108.33). ${ }^{34}$

He then concludes his epitathium to her by first invoking the well-known verse of Horace (2004), Carm. 3.30.1: exegi monumentum aere perennius, quod nulla destruere possit uetustas '(In this letter) 'I have built' (to your memory) 'a monument more lasting than bronze', which no lapse of time would be able to destroy' (Ep. 108.33), and finally by adding the words inscribed on her tomb.

Indeed Jerome has created a lasting monument, not only with the grave inscriptions in stilted hexameters but especially with this multilayered work of literature, embellished with rhetorical artistry, with which he bestowed literary immortality upon Paula. In this consolatio, eclipsed by an encomium with considerable biographical content, he portrayed an icon for his own ascetic ideology, and an exemplary representative of his own theological, scholarly and ascetic agenda. ${ }^{35}$

\section{Acknowledgements Competing interests}

The author declares that she has no financial or personal relationships which may have inappropriately influenced her in writing this article.

\section{Both as author of Epistula 108 and as her mentor}

34.In this case the translation is my own. Cain (2010) argues for an interpretation of Epistula 108 as the textual basis for a Bethlehem-centred cult of Paula, the ascetic martyr-saint, based primarily on a translation of the noun cultoris in Ep. 108.33 as 'worshipper/votary'.

35.With acknowledgement to the insight of Cain (2010:137-138).

\section{References}

Corpus Scriptorum Ecclesiasticorum Latinorum [CSEL] Vol. LIV. S. Eusebii Hieronymi. Opera (Sect. I, Pars I). Epistularum Pars I. MDCCCCX, Recensuit Isidorus Hilberg, F. Tempsky, Vindobonae.

Corpus Scriptorum Ecclesiasticorum Latinorum [CSEL] Vol. LV. S. Eusebii Hieronymi. Opera (Sect. I, Pars II). Epistularum Pars II. MDCCCCXII, Recensuit Isidorus Hilberg, F. Tempsky, Vindobonae.

Gregory of Nazianzus, 1992, 'Orationes 42-43', in J. Bernardi (ed.), Grégoire de Nazianze: Discours 42-43, Sources Chrétiennes 384, Cerf, Paris.

Horace, 2004, Odes and epodes, The Loeb Classical Library, transl. N. Rudd (ed.), Harvard University Press, Cambridge, MA.

Jerome, 1845, De Viris Illustribus. In: Migne, J-P. Patrologiae Cursus Completus, Series Latina, Vol. 23, pp. 602-720, Paris.

Jerome, 1983, The principal works of St. Jerome, transl. W.H. Fremantle, NPNF Vol. 2-06, P. Schaff \& H. Wallace (eds.), WMB, Eerdmans Publishing Company, Grand Rapids, MI.

Pliny the Younger, 1992, C. Plinii Caecili Secundi Epistularum Libri Decem, R.A.B. Mynors (ed.), Clarendon Press, Oxford.

Virgil, 1978, Opera omnia. Vol. I. Eclogues, Georgics, Aeneid I-VI, The Loeb Classical Library, transl. H.R. Fairclough, Harvard University Press, Cambridge, MA.

\section{Secondary sources}

Aune, D.E., 1988, Greco-Roman literature and the New Testament: Selected forms and genres, Society of Biblical Literature, Atlanta, GA

Barton, S.C., 2006, The Cambridge companion to the Gospels, Cambridge University Press, Cambridge.

Botha, P.J. \& Kritzinger, J.P.K., 2013, 'Rhetoric and argument in chapter VI of Jerome's Vita Malchi Monachi Captivi', Ekklesiastikos Pharos 95, 283-293.

Burridge, R.A., 1992, What are the Gospels? A comparison with Graeco-Roman Biography, Cambridge University Press, Cambridge.

Burridge, R.A., 2013, 'Biography as the Gospels' Literary Genre', RCatT 38(1), 9-30.

Burrus, V., 2001, 'Queer lives of saints: Jerome's hagiography', Journal of the History of Sexuality 10(3/4), 442-479, viewed 06 May 2016, from http://jstor.org/stable/3704756

Cain, A., 2006a, 'Origen, Jerome, and the "Senatus Pharisaeorum"', Latomus 65(3) 727-734, viewed 20 September 2016, from http://www.jstor.org/stable/41544217

Cain, A., 2008, 'Liber manet: Pliny, Ep.9.27.2 and Jerome, Ep. 130.19.5', Classical Quarterly 58(2), 708-710. https://doi.org/10.1017/\$0009838808000840

Cain, A., 2009a, 'Jerome's Epistula CXVII on the Subintroductae: Satire, Apology, and Ascetic Propaganda in Gaul', Augustinianum 49(1), 119-143. https://doi. org/10.5840/agstm200949123

Cain, A., 2009b, The letters of Jerome: Asceticism, biblical exegesis, and the construction of Christian authority in late antiquity, Oxford University Press, Oxford.

Cain, A., 2010, 'Jerome's Epitaphium Paulae: Hagiography, pilgrimage, and the cult of Saint Paula', Journal of Early Christian Studies 18(1), 105-139. https://doi. org/10.1353/earl.0.0310

Clark, E.A., 1981, 'Ascetic renunciation and feminine advancement: A paradox of late ancient Christianity', Anglican Theological Review 63(3), 240-257.

Clark, E.A., 1986, Ascetic Piety and Women's Faith. Essays on Late Ancient Christianity, Studies in Women and Religion 20, Edwin Mellen, Lewiston.

Clark, E.A., 1999, Reading renunciation. Asceticism and scripture in early Christianity, Princeton University Press, Princeton, NJ.

Clark, G., 1995, 'Women and asceticism in late antiquity: The refusal of status and gender', in V.L. Wimbush \& R. Valantasis (eds.), Asceticism, pp. 33-48, Oxford University Press, New York.

Coleiro, E., 1957, 'St. Jerome's lives of the hermits', Vigiliae Christianae 11(3), 161-178, viewed 13 May 2016, from http://jstor.org/stable/1582215

Cox Miller, P., 1993, 'The blazing body: Ascetic desire in Jerome's letter to Eustochiue', Journal of Early Christian Studies 1(1), 21-45. https://doi.org/10.1353/earl.0.0133

Curran, J.R., 2000, Pagan City and Christian Capital. Rome in the fourth century, Clarendon, Oxford.

Diederich, M.D., 1954, 'The Epitaphium Sanctae Paulae', The Classical Journal 49(8), 369-372, viewed 13 May 2016, from http://www.jstor.org/stable/3292915

Farmer, D.H., 2011, The oxford dictionary of saints, 5th rev. edn., Oxford University Press, New York.

Favez, C., 1937, La consolation latine chrétienne, Vrin, Paris.

Hägg, T. \& Rousseau, P. (eds.), 2000, Greek biography and panegyric in late antiquity, University of California Press, Los Angeles, CA.

Hickey, A.E., 1987, Women of the roman aristocracy as Christian monastics, UMI Research, Ann Arbor, MI.

Hillman, M.L., 2012, 'Graeco-Roman Bioi and the Gospels', Honors theses, Paper 2042 , viewed 05 May 2016, from http://scholarworks.wmich.edu/honors-theses

Hritzu, J.N., 1943, 'St. Jerome, the Christian Cicero', The Classical Weekly 36(20), 230-231. https://doi.org/10.2307/4341694

Kelly, J.N.D., 1975, Jerome. His life, writings, and controversies, Duckworth, London.

Kraemer, R.S., 2008, 'Women and gender', in S.A. Harvey \& D.G. Hunter (eds.), The Oxford handbook of early Christian studies, pp. 465-492, Oxford University Press, New York. 
Littlechilds, R.L., 2014, "If you wish to be my mother, take care to please Christ": The post-humous speech of Blesilla in Jerome's Letter 39', Journal of Early Christian post-humous speech
History 4(1), 97-111.

McNamara, J.A., 1984, 'Cornelia's daughters: Paula and Eustochium', Women's Studies 11, 9-27. https://doi.org/10.1080/00497878.1984.9978602

Momigliano, A., 1993, The development of Greek biography, Harvard University Press, Cambridge, MA.

Scourfield, J.H.D., 1993, Consoling Heliodorus - A Commentary on Jerome, Letter 60, Clarendon, Oxford.
Simpson, J., 1988, Women and asceticism in the fourth century: A question of interpretation, The Journal of Religious History 15(1), 38-60. https://doi. org/10.1111/j.1467-9809.1988.tb00516.x

Weingarten, S., 2005, The saint's saints: Hagiography and geography in Jerome, Brill, Leiden.

Wimbush, V.L., 1993, 'The ascetic impulse in ancient Christianity', Theology Today 50(3), 417-428. https://doi.org/10.1177/004057369305000308

Yarbrough, A., 1976, 'Christianization in the fourth century: The example of Roman women', Church History 45(2), 149-165, viewed 11 May 2016, from http://www.
jstor.org/stable/3163714 